\title{
SOCIAL SAFETY NET PROGRAMMES AND ITS IMPACT ON LIVELIHOOD: A CASE STUDY OF BANGLADESH
}

\begin{abstract}
Bangladesh has been implementing social safety net programmes (SSNP) to protect vulnerable groups of people. Old Age Allowance (OAA) and Allowances for the Widows, Deserted \& Destitute (AWDD) are two unconditional cash transfer programmes under the SSNP for vulnerable old age people and women, respectively. The impact of these programmes are examined in two upazilas (sub-districts) of the poorest district of Kurigram: Roumari upazila, which is comparatively better off, and Rajibpur upazila, which is the poorest. Natural disasters and remoteness are the reasons for this region's vulnerability. In-depth interviews were conducted with twenty recipients to understand the implications of the allowance's' impact on their livelihoods. The findings reveal that the allowance contributes to necessary food consumption and acts as a coping mechanism during natural shocks. However, asset building and resource diversification are important to ensuring a sustainable livelihood. A small cash transfer is not enough for recipients to save and diversify their income growth. The allowance has minimal or no impact on the mediation of other capital assets like access to natural resources or social capital. Working-age recipients rely heavily on agriculturalbased activities, but they do not own the land they farm. SSNP does not offer suitable cultivation practices, such as training that could fortify living capabilities or, sufficient resources to encourage career development. Additionally, a number of the beneficiaries are beyond working age. Aside from various factors like malpractice and usury, cash transfer systems have an adverse impact on OAA/AWDD, which reduces the value of allowances. The allowances from SSNPs provides a minimum support for survival but not
\end{abstract}

Saifur Rahman- PhD candidate, Department of Politics, East China Normal University, Shanghai, China.Email: Saifur.rahman27@yahoo.com 
enough to generate income and asset building capabilities. Hence, it is hard for beneficiaries to achieve a sustainable livelihood.

Keywords: the social safety net, unconditional cash transfers, livelihood, old age allowance, allowances for widows, the deserted and destitute

DOI: 10.17323/727-0634-2020-18-1-129-142

\section{Introduction}

The northern part of Bangladesh is often stricken by Monga- a Bengali term for a form of seasonal famine that hits the region twice a year. The most severe term prevails from mid-September to mid-November and the less severe term is from mid-March to mid-May. This causes problems for employment and income opportunities in between transplantation and paddy harvests (Zug 2006). The situation becomes more severe if floods, riverbank erosions, or droughts occur during Monga. Mohammad Ansari and Peter Atkins (2014) have noted that this incident prevails over five northern districts of Bangladesh, including Kurigram. From Golam Rabbani and Solaiman Chowdhury (2014) we gain insight into regions prone to Monga occurrences. In this region, $80-90 \%$ of the people are employed in the agricultural sector. It is estimated that $54 \%$ of people in this region are employed and $60 \%$ of this group work 110 to 160 days a year. Their labour wage is the lowest in the northern districts of Monga-prone region and during Monga some people only have a meal once a day or even once every two to three days. The poorest suffer more diseases due to insufficient and unsafe food. The government has distributed food through various Social Safety Net Programmes (SSNP) as a response to Monga.

Bangladesh introduced SSNP in 1974. At the beginning of SSNP the main concept and nature of this programme were public works and food aid. Over the last four decades the form of assistance has changed. Currently both protective and preventive types of SSNP, namely conditional and unconditional SSNP, are being implemented. National and international sources report that Bangladesh has achieved no progress with respect to the indicators of Human Development Index (Human Development Report 1997) in the past few decades. Despite different initiatives to develop and improve the livelihood of marginalised people, the Kurigram district preserves the highest rate of poverty (HIES 2010). Moreover, Monga has attracted considerable media coverage. Thus, it has become a political issue and been included in Bangladesh's Poverty Reduction Strategy Paper. SSNP is a mechanism to assist vulnerable groups. It is important to understand the impact SSNP has on its beneficiaries' livelihoods. Considering the above mentioned the central question of this research is: Do Social Safety Net programmes have an impact on livelihood?

The Kurigram district is the focus of investigation because it is the district with the highest level of poverty and is often hit the hardest during Monga. 
There are two SSNPs that are considered for this study: Old Age Allowances (OAA) and Allowances for the Widows, Deserted \& Destitute (AWDD). These two SSNPs offer unconditional cash transfers (UCT) and enlisted recipients can receive these benefits for a long period of time.

\section{Empirical and Theoretical Context}

Across the world SSNPs have a divergent impact on livelihoods and raising recipients out of poverty. In Malawi, beneficiaries of the social cash transfer programme (SCTP) receive between 4.30 and 12.85 USD per month. During periods of food insecurity the SCTP improved recipients' livelihood and reduced hunger (Miller et al. 2011). In southern African countries it was found that SSNPs had a multi-dimensional impact on their participants. Stephen Devereux (2000) conducted a comparative study of three countries-Mozambique, Namibia and Zambia - in regards to SSNP. The 'Office for Assistance to the Vulnerable Population' (GAPVU) is one kind of UCT programme in Mozambique. The small amount of cash under the GAPVU has the most impact on the basic daily needs of its beneficiaries. In Namibia, the 'Social Pension' programme has the greatest impact on living patterns in diverging ways. It is a non-contributory type of social security assistance. In Zambia, the 'Cash for Work SSNP' had a positive impact on recipient livelihoods and has provided a range of unexpected impacts. What is remarkable in these three countries is the relationship between the amount of assistance and the impact on SSNP outcomes. In Mozambique the small amount provided by GAPVU had a negligible impact. By contrast, the slightly greater but still moderate Social Pension in Namibia and 'Cash for Work' in Zambia had more impact on income generating activities.

A comparative study of the impact of four SSNPs was conducted in Bangladesh, with a focus on the Kurigram district, among others (Ahmed et al. 2009). The four SSNPs are the Income-Generating Vulnerable Group Development (IGVGD), the Food Security Vulnerable Group Development (FSVGD), the Food for Asset Creation (FFA) and the Rural Maintenance Program (RMP). The IGVGD provided food transfers, the RMP provided cash payments, and the FSVGD and the FFA both provided combination transfers of food and cash. The RMP has a four-year cycle and the other three programmes a two-year cycle. Overall, the findings showed that the food consumption and household income of the recipients under the four SSNPs increased and extreme poverty was reduced. IGVGD participants who attended training for their livestock assets increased the value of their livestock three times more when compared to those who did not attend the training. RMP beneficiaries had the largest amount of savings due to higher savings requirement compared to rest of the three programmes. FSVGD participants' livelihood indicators improved during the programme period, but they were not able to maintain 
this level after leaving the programme. The FSVGD has neither a moderate savings requirement nor a mechanism to access micro-credit (only IGVGD has). Other research (Siddiki et al. 2014) assessed the impact of the 'Char Livelihood Programme' (CLP) and the IGVGD, taking the Kurigram district as the object of their study. Under the CLP, beneficiaries received assets such as livestock whose financial value is worth approximately USD 200. IGVGD recipients living in the Hill tract area received 30 kilogrammes of rice a month ${ }^{1}$ (including training) for two years. After a year, the CLP had strengthened the recipients' income generation activities divergently. In the case of the IGVGD, the annual income of treated households increased more impressively than control group households. The above-mentioned empirical findings, in both national and international cases, show that the size of transfer plays an influential role in the recipient's livelihood. Recipients of OAA and AWDD have been receiving approximately 5.19 USD per month. It is worthwhile to analyse how this amount of money is enough to change the living patterns of beneficiaries.

One group of researchers (Khandker et al. 2011) found that SSNPs had positive impacts in reducing starvation in the Monga-prone area and the OAA programme dealt with those who were most likely to be at risk. According to other research (Mazumder, Wincing 2012), starvation, one meal per day, borrowing money, selling assets, and state support were surviving mechanisms during Monga. There has been a trend of migration away from Monga areas. This kind of internal migration within the country has other socio-economic impacts (Sultana 2010). This migration is one kind of coping mechanism for people experiencing this shock.

Theoretically, assets are important for livelihood systems. Assets and productive investment diversify living strategies, while financial capital mediates gained assets. Robert Chambers and Gordon R. Conway (1992) stated that livelihood comprises the capabilities, assets and activities for a means of living. Others (Hoon et al. 1997) have argued that the conditions of sustainable livelihoods are (a) the empowerment approach to poverty reduction; (b) creating sustainability by targeting issues of poverty and environment and by boosting participation; (c) development in both social and economic aspects. Coping and adaptive strategies are crucial in a sustainable livelihood system; these are framed within a tripartite context of human ecology, expanded entitlements, and policy matrix.

A framework of assets such as natural, social, physical, financial, and human capital play pivotal roles in achieving livelihood strategies to reduce vulnerability (DFID 1999). A range of assets provides the potential to achieve positive livelihood outcomes. Human capital is necessary to make use of the other four types of capital. Social capital improves economic relation effi-

\footnotetext{
${ }^{1}$ IGVGD, recipients have received $30 \mathrm{Kg}$ of rice, which is priced at about Tk. 900 or USD 11.67, Suppose $1 \mathrm{Kg}$ rice $=$ Tk. 30 .
} 
ciency, natural capital is a vital source to produce food (fishing, farming), physical capital (affordable transport, energy, water supply) supports services, and financial capital is necessary to achieve desired outcome using livelihood strategies (ibid). Furthermore, the three core livelihood strategies are agricultural intensification, livelihood diversification and migration (Scoones 1998). Livelihood systems were assessed based on five assets of the above-mentioned strategy presented by the Department for International Development (DFID) in a diversification lens. Diversification of livelihood increases human capital, in terms of experience, and generates earnings which is done by earning assets that in turn reduces vulnerability (Ellis 1998, 1999; Ellis, Allison 2004).

Thus, the different livelihood approaches can be summed up as follows: assets are an important factor for livelihood outcome. Diversification and access of resources mediates livelihood strategies and coping mechanism during shocks. Empirical findings show that the amount of money and training plays an important role on livelihood system. Therefore, the main objective of this study is to examine the impact of SSNPs on respondents' livelihoods in the poorest upazila, namely Rajibpur, and the better-off Roumari in the Kurigram district. Identifying socio-economic factors of respondents that differentiates the poorest from the better off upazilas gives researchers and policymakers insights to create more effective policies. A total of twenty beneficiaries were interviewed from the Rajibpur and Roumari upazilas. Ten beneficiaries were randomly selected from each upazila. In the AWDD programme all were women but in the OAA programme the beneficiaries were of both genders. Most of the interviewees were illiterate and all of respondents were over 45 years old. The respondent's allowance receiving period ranged from 1.5 to 14 years. The OAA and AWDD beneficiaries' annual income is less than 40 and 160 USD, respectively. Their occupations are diversified as day labour, tailor, unemployment (unable to work because of age), and house wife. In-depth interviews were conducted to fulfil the purpose of this research, which takes a qualitative case study approach to assess the impact of OAA/AWDD on beneficiaries.

The procedure used to answer the research question was adopted from the DFID (1999) livelihood approach. Allowances are considered as one source of financial capital in contexts of vulnerability. Strategies that improve livelihood outcomes are categorized into three streams, namely food consumption patterns, income generation activities and coping mechanisms during natural disasters. The analysis of the impact of OAA and AWDD considers the following: changes in respondent food consumption patterns (frequency of taking a meal, food production, and food processing), income generation (productive investment, income activities, development), and coping mechanisms (preparation, compensation, survival during Monga). The collected data has also been analysed to understand the socio-economic differences between the respondents of two upazilas. 


\section{Analysis}

\section{Differences between the respondents' socio-economic statuses in the two upazilas}

Roumari upazila is more advanced than Rajibpur upazila in terms of the number of respondents with some level of education. While most of them have no education qualification certificate, more respondents from Roumari upazila can read and write than Rajibpur upazila. If property is considered, most of the respondents of Rajibpur upazila have no property, whereas more respondents of Roumari upazila own property, albeit still a very small percentage. The trend to migrate to other districts in search of income is different for the two areas' respondents. From Roumari upzila, three respondents mentioned that they temporarily migrated to other districts of the country in search of employment. Two recipients from Rajibpur upazila mentioned temporary migration for employment.

Receiving the benefits studied in this paper is not a straightforward process for the interviewees. Thus, bribery as an entry point was mentioned and something that was believed to undermine the output and aim of SSNP. One recipient of Rajibpur upazila gave 3000 Tk. (39 USD approximately) to become a union member (a member of local government) to enrol him in SSNP. The monthly allowance is approximately 5.19 USD, but he paid more only to be enlisted on the OAA. At the same time there was no complaint of malpractice from beneficiaries in Roumari upazila. Besides, the majority of targeted recipients in Rajibur have received rice and blankets during floods from local and international NGOs. Hence, the targeted recipients of OAA/AWDD of Rajibur upazila receive other benefits from the state and NGOs in comparison to Roumari upazila. Also, respondents of Rajibpur upazila tend to borrow money from NGOs. This kind of loan is charged with high return. The borrowers are laid with the extra burden of paying their debts. An allowance recipient (Y3), a 70-year-old woman from Roumari upazila, said:

Though I have to live with hardship, I don't borrow money from interest mongers. I borrow from neighbours. When allowance money is at hand, I repay with that. I myself cannot lend to anybody, I just pass through life somehow.

Education, property, availability of extra assistance could be determinate factors of livelihood of two upazilas. However, we should be careful to not make generalizations without further studies of the benefits each upazila receives.

\section{The role of SSNPs on food consumption patterns}

Food consumption power is one kind of determinant to measure poverty levels. The frequency of meals per day indicates how the allowance promotes the livelihoods of the poor. All of the respondents confirmed that the OAA and 
AWDD are helpful in supporting their food habit strategies. According to one allowance recipient (X1), an 81-year-old man, from Rajibpur upazila:

Allowance plays a role in food intake or food habit. Earlier I had to depend solely on my earning for buying food. Now allowance money works as extra assistance. Food can be bought with my earnings plus allowance money. Besides, with the allowance food grains can be bought and stored for future need.

If we consider the general expectation of consuming a meal as three times a day, then an increase in food intake frequency means that the consumption pattern is improving and hunger is reduced. In Roumari upazila, three respondents said the frequency of daily intake had increased after receiving the allowance. Before the SSNP support they only ate twice or less per day. A similar effect was also seen in Rajibpur upazila where four respondents out of ten had fewer than three meals per day. All SSNP recipients consumed meals three times per day. Both programmes have had an influence on increasing the frequency of meals. We can see that the AWDD programme has had more impact on those enrolled in the programme.

As for impact on food production, it is important to say first that respondents cultivate their homestead yards, state alluvial land and land from the land lord. The inhabitants of these areas enjoy the river sand bar without any legal ownership of land and also cultivate leased land under some conditions. All respondents said the allowance is very important for them to produce rice, vegetables and in some cases sugarcane. The cost of sowing seeds and fertilizer for low-scale farming is not expensive. The land is fertile and alluvial which is good for growing vegetables. The SSNP allowance was helpful for buying paddy seeds, fertilizer and even for watering. OAA respondents were mainly working in rice paddy production, whereas AWDD respondents mainly produce vegetables.

Another aspect of food consumption patterns is the impact on food processing. The allowance plays an important role in rice processing. In remote areas harvesting paddy and processing rice are done in the traditional way. There are many steps to process rice such as sopping, parboiling, husking, drying and so on. There are three main steps of rice processing for which interviewees receive funding. Harvesting (cutting, staking), husking (threshing, cleaning) and milling are important processes for food processing. Most of the respondents mentioned the allowance had an influential role for the aforementioned food processing. OAA recipients were most likely to use their allowance for husking, while AWDD respondents were most likely to use their allowances for milling.

\section{The role of SSNPs on assets-income generation activities}

An allowance recipient (Y1), a 60-year-old woman, from Roumari upazila, has been receiving AWDD for about twelve years. She commented: 
If I could buy goats, poultry with the widow allowance, it would increase my income. A goat costs 2000 Tk. How can I buy a goat with this money? Only 5 or 6 poultry can be bought with this allowance, and how can these 5 or 6 poultry be the means of my sustenance? If I buy poultry with allowance money, I have to pass days with hardship, because I don't have money to buy food.

An allowance recipient (Y2), a 70-year-old woman from Rajibpur upazila, has been receiving AWDD for five years. Her reflection was:

I don't have land of my own. My house is on the roadside on government owned land. Poultry, furniture, and savings - I have nothing of these things. Allowance money has no role in earning income and property because it is meagre. I work as a day labourer in other people's homes. There is no difference between what I used to do earlier before getting allowance and what I do now. Widow allowance has no role in changing my occupation.

These reflections lead to conclusions about the impact of allowances on building the recipients' assets. Assets have an inherent power to reduce vulnerability. Livestock, poultry, rickshaws (local transport), vans, boats, carts, etc. are considered to be valuable assets in the area. If those items can be bought, it secures one's income level. The majority of interviewees claimed that the amount of allowance was not enough to buy any kind of assets. Similarly, respondents mentioned that allowances could not contribute to productive investment (like small entrepreneurship, farm, agricultural business, handicraft business etc.). Even though the allowance is not enough to encourage asset building and productive investment, OAA respondents have other resources to improve their income generation activities compared to those in AWDD. If there are more earnings per person in a family and more borrowing money from NGO's, then SSNPs have a minimal role in making productive investments.

The allowances have an impact on income activities. Transportation cost to reach a work place, warm clothing for work, extra work as a petty trader are all income-related activities or, in other words, investments one makes in order to earn money. Only one of the respondents from each upzila could use their allowances for these daily income activities. Half of the respondents from both upzilas mentioned that the allowance made no contribution to the income activities. The remaining interviewees agreed that the allowance played an indirect role for income. The collected data mostly indicates that the OAA/AWDD had no influential impact on occupation transformation. Again, half the OAA recipients mentioned that the allowance had an impact on income generation activities and all beneficiaries said there was no relation between the allowance and any change of profession. Among the AWDD recipients, half commented that the allowance strengthened their daily income activities explicitly and implicitly and the majority mentioned that the social assistance money did not result in a change in their occupations.

When consider the impact on development, it is important to look at SSNPs influence on healthcare, children's' education and training, empowerment, and 
social status. An allowance recipient (X2), an 85-year-old man from Roumari upazila, said:

If the allowance were a little bit more, then perhaps I could buy some poultry to set up a firm. With what I get I can only lead my life somehow like buying rice or medicine some times. Before I worked as a day labourer. Now I have not the ability to do any work, so I depend solely on the allowance. I have nothing more than the homestead.

In Rajibpur upazila the majority of respondents asserted that SSNPs contributed to health and two respondents and remarked that the allowance has implications on developing human resources. In Roumari upazila respondents also agreed that SSNPs are helpful for buying medicine and they used the aid money for their children's education. Overall, more AWDD interviewees compare to OAA said that the allowance is necessary to pay for the cost of their children's education. Again, the same number of AWDD and OAA respondents said that the allowance helped them with health expenditure.

\section{The role of SSNPS}

\section{on coping mechanisms against natural disasters}

Natural disasters affect those at the margins of society the most. SSNPs can reduce the level of vulnerability. An 81-year-old man (X3) from Rajibpur upazila made the following comment:

Natural calamities bring suffering. All the prices go up. Roads and homestead go under water. At this point the allowance money is the only thing to rely on because there is no work then to earn money. People and property are much affected in a flood. The allowance helps maintain life, it makes people better off.

It is worth considering the possible impacts of the allowances on various aspects of natural disasters. First of all, being prepared for Monga is important as it reduces victim's' suffering. A food crisis situation becomes more severe during natural disasters and the lack of clean water increases its severity. It creates problems for accommodation, communication and cooking. During floods, most houses are underwater. Respondents from Rajibpur upazila described two issues which are related to their readiness against natural disasters. One issue is related to food stocks, while the other one is concerned with the homestead. The majority of respondents from both upazilas stated that the allowances were the underlying reason they were able to stock some food for the near future to cope during a period of devastation. A few respondents mentioned the allowance is helpful for homestead activities (home and adjoining land for a family to live in) and for buying winter clothes and transferring important belongings to a secure place during a natural disaster.

Secondly, consider the impact on compensation for the loss incurred by natural disaster. Respondents from the Rajibpur upazila mentioned that they 
could repair and reconstruct their devastated habitat by using the allowance money. The allowance was helpful to buy bamboo, rope, and a few pieces of iron sheets if they do the repairs themselves or to pay for a carpenter. A few of the respondents reported that the SSNP allowance was only enough to buy rice. All respondents from Roumari upazila agreed that the OAA/AWDD was really helpful after the devastation when rebuilding their houses. Even support in taking their valuable belongings to a safe place was helpful. All of the female interviewees mentioned that the AWDD was helpful for housing reconstruction and to keep valuables safe. In addition, a substantial number of respondents from OAA also agreed that the allowance had an effect on rebuilding their devastated homes.

The allowances also impact surviving. During Monga people still make an attempt to find work. During this period of time, it is almost impossible to earn for living. All of the twenty respondents mentioned that they spent idle hours during Monga. In this period, the allowance money is the sole way for meeting ends. They use their savings to meet their daily necessities. The allowance is relied on as an extra income. It also provides a psychological boost. Most of respondents said the OAA and AWDD programmes played an important role in supporting marginalized people and keeping them away from the vicious cycle of borrowing.

\section{Discussion}

The OAA and AWDD have impacts on the frequency with which respondents have meals, produce vegetables and rice paddies, and process rice. SSNPs have a marginal impact on health care, education costs, and buying warm clothes and simple tools for work. However, gaining assets (livestock, poultry, boats, vans) or productive investments (handicraft business, small entrepreneurship) with the allowance is hard. SSNPs help respondents to prepare for Monga (like hoarding rice, homestead), make home repairs, and allowances are the sole way to survive. This result complies with other research findings. Mohammad Mahbubur Rahman (2012) found that although general recipients in Bangladesh used the allowance for food and not for non-food items, still the allowances are mainly spent on food so that recipients survived during crisis. A number of other studies also confirm these findings (Bushamuka et al. 2005; Khaleque et al. 2008); Khan 2012; Uddin 2013; Ansari 2013; World Bank 2006).

Assets are the underlying determinants for generating income as well as changing the approach to livelihood (Winters et al. 2002). Theoretical and empirical analysis provides insight into the importance of assets and resource diversification for sustainable livelihood, where the size of the allowance is an underlying factor. First, OAA/AWDD only provides a little amount of cash flow. It does not mediate the other types of capital that are mentioned by DFID. 
For example, participants of OAA/AWDD do not receive any training to enhance their capabilities. Moreover, recipients are not gaining access to natural resources. Besides, poor physical capital deducts the money value of allowance. Malpractice was found in SSNPs and the allowances of SSNP are undercut by paying other kinds of debts and bribes. Second, the beneficiaries' income and allowance are not enough to fulfil their basic necessities so they cannot amass savings. The low savings rate is a constraint for asset building and this undermines people's economic power and pushes them into poverty (UN Millennium Project 2005). SSNPs have an impact on food stocks, but not other resources such as buying livestock, farm equipment. Third, recipients are highly reliant on agricultural-based activities despite not having their own land. OAA and AWDD do not promote the diversification of cultivation practices. Again, the allowances have no impact on job changes, but there is indication of some impact on internal migration to seek jobs. Less intensification of agriculture, migration and diversification does not improve respondents' capabilities. In a nutshell, OAA and AWDD plays a role in food consumption patterns and as a coping mechanism, but has no remarkable impact on income generation strategies.

Ways to diversify living opportunities by different policies and without any major financial implication is discussed below. First of all, Bangladesh has experience in sending workers to other countries. Regarding this issue recently a few Memoranda of Understanding (MoU) have been signed with some countries which are known as Government to Government (G2G) agreements. Considering this notion two steps are imperative: the inhabitants of Kurigram district who are under the poverty line should gain preference in traveling for jobs under these agreements; necessary costs can be managed through existing governmental mechanisms (such as the Expatriate Welfare Bank of Bangladesh).

Secondly, the State is the owner of island/sand bar in Kurigram. According to the socio-economic ramification the government can encourage cultivation of this sand bar and permit ploughing. The government can provide support for crops and distribution. Besides, garments sector is a thriving economic activity in the region where female workers have a significant presence and preference. The government can ask the garment owners to impose a quota system in the nearest garment factory to motivate hiring workers from poverty prone areas.

Thirdly, working age beneficiaries need special attention because of their age. Beneficiaries of OAA may receive preference in a public food distribution system and allocation of places in state care homes. When the food security improves, the OAA/AWDD can be used to generate activities by engaging the family's wage-earning members. Moreover, the allowances received through the traditional banking channels are inconvenient for old-aged people because physical movement is limited and transportation costs are high. Allowance distribution through mobile banking can be a better option to eliminate unnecessary costs. Moreover, an integrated safety net service delivery system can reduce organizational procedures and expenditure, ensure equity and build resil- 
ience. An efficient and recipient friendly payment schedule using the shortest possible procedure can have a positive impact on beneficiaries' livelihoods.

Finally, building a usable social network in Monga-prone areas helps to disseminate information, awareness and good decision-making to utilize allowances in strategically. Linking other services like healthcare into this social network will have a huge impact on livelihood and its transformation into a sustainable way of life.

\section{Conclusion}

Kurigram is the poorest district of Bangladesh and periods of Monga make it difficult for vulnerable people. The government has been implementing SSNPs for affected people. To find out the impact of SSNPs on livelihood qualitative data were collected from two upazilas of the Kurigram district. The findings are that OAA and AWDD plays a substantial role for buying, producing and processing food for respondents. It also plays an important role during Monga in various ways like preparation against shocks, compensation for the loss incurred by natural disasters.

At the same time there is no noticeable role of OAA/AWDD in gaining any kind of assets of respondents. It is slightly helpful for human development which can bring a positive output after some time. Ultimately, respondents' property and income levels remain the same in two ways. First, food insecurity keeps them in a vulnerable position and most of the money is spent on food. Second, job scarcity, health condition, natural calamity, and price hiking affect target recipients' source of income negatively and cause their earnings to fluctuate. The incomes of vulnerable people remain the same in conditions of natural disaster, or drop, which is the cause of the poverty trap (Banerjee, Duflo 2011: 191-193).

OAA and AWDD cannot enhance the capabilities of respondents for long term adaptive strategies but they remain coping mechanisms during Monga. They provide support but are not enough to transcend the poverty trap to achieve a sustainable livelihood. To formulate an intensive and economically efficient social safety net, focus should be given not only on survival, but on income generation.

\section{References}

Ahmed A.U., Quisumbing A.R., Nasree M., Hoddinot J.F., Bryan E. (2009) Comparing Food and Cash Transfers to the Ultra Poor in Bangladesh. Washington, DC: International Food Policy Research Institute. 
Ansari A. M.N. (2013) Hunger, Place and Seasonality: Understanding Monga Vulnerability in North West Bangladesh. Available at: http://etheses.dur.ac.uk/9439/1/ PhD_thesis_M_N_A_ Ansari_000067310.pdf (accessed 22 January 2018).

Ansari M., Atkins P. (2014) Understanding the Monga in Northwest Bangladesh: Household Perceptions and Perceptual Connotations. International Research Journal of Social Sciences, 3 (8): 22-29.

Banerjee A. V., Duflo E. (2011) Poor Economics - A Radical Rethinking of the Way to Fight Global Poverty. New York: Public Affairs.

Bushamuka V.N., de Pee S., Talukder A., Kiess L., Panagides D., Taher A., Bloem M. (2005) Impact of a Homestead Gardening Program on Household Food Security and Empowerment of Women in Bangladesh. Food \& Nutrition Bulletin, 26 (1): 17-25.

Chambers R., Conway G. R. (1992) Sustainable Rural Livelihood: Practical Concept for the 21st Century. Available at: http://publications.iwmi.org/pdf/H_32821.pdf (accessed 27 October 2018).

DFID (1999) Sustainable Livelihoods Guidance Sheets. Available at: http://www.eldis.org/ vfile/upload/1/document/0901/section2.pdf (accessed 20 December 2017).

Devereux S. (2000) Social Safety Nets for Poverty Alleviation in South Africa. Available at: https://www.ids.ac.uk/files/dmfile/Devereux2000.pdf (accessed 26 December 2017).

Ellis F. (1998) Household Strategies and Rural Livelihood Diversification. The Journal of Development Studies, 35 (1): 1-38.

Ellis F. (1999) Rural Livelihood Diversity in Developing Countries: Evidence and Policy Implication. Available at: http://dlc.dlib.indiana.edu/dlc/bitstream/handle/10535/4486/40rural-livelihood-diversity.pdf (accessed 29 October 2018).

Ellis F., Allison E. (2004) Livelihood Diversification and Natural Resources Access. Livelihood Support Program. Available at: http://www.fao.org/3/a-ad689e.pdf (accessed 13 October 2018).

HIES (2010) Household Income and Expenditure Survey. Dhaka: Bangladesh Bureau of Statistics (BBS), Planning Division.

Hoon P., Singh N., Wanmali S. (1997) Sustainable Livelihoods: Concepts, Principles and Approaches to Indicator Development. New York: UNDP.

Human Development Report (1997) United Nations Development Programme. New York: Oxford University Press.

Khan N. J. (2012) An Assessment of Widow Allowance Programme in Bangladesh-the Supply Side Perspectives. Available at: http://www.mppg-nsu.org/attachments/396_Nilufar.pdf (accessed 12 February 2018).

Khaleque K., Suborna B., Baqui B. (2008) Impact of Social Safety Net Programs in Seasonal Deprivation. Available at: https://mpra.ub.uni-muenchen.de/22045/ (accessed 27 Feb ruary 2018).

Khandker S. R., Khaleque M.A., Samad H.A. (2011) Can Social Safety Nets Alleviate Deprivation? Evidence from Northwest Bangladesh. Available at: https://openknowledge.worldbank. 
org/bitstream/handle/10986/3631/WPS5865.pdf?sequence=1\&isAllowed=y (accessed 26 February 2018).

Mazumder M. S. U., Wincing L. (2012) Monga Vulnerability in the Northern Part of Bangladesh. African Journal of Agricultural Research, 7 (3):358-366.

Miller C.M, Tsoka M., Reicherta K. (2011) The Impact of the Social Cash Transfer Scheme on Food Security in Malawi. Food Policy, 36 (2):230-238.

Rabbani G., Chowdhury S. (2014) Social Safety Net for Employment Generation and Capacity Development: Current State and Policy Dynamics. Global Journal of Management and Business Research: Administration and Management, 14 (5):21-29(25).

Rahman M. M. (2012) Estimating the Effects of Social Safety Net Programmes in Bangladesh on Calorie Consumption of Poor Household. Bangladesh Development Studies, 35 (2): $67-85$.

Scoones I. (1998) Sustainable Rural Livelihoods a Framework for Analysis. Available at: https://www.researchgate.net/publication/270588972 (accessed 20 October 2018).

Siddiki O.F., Holmes R., Jahan F., Chowdhury F. S., Hagen-Zanker J. (2014) How do Social Safety Nets Contribute to Social Inclusion in Bangladesh? Evidence from the Chars Livelihoods Programme and the Vulnerable Group Development Programme. Available at: http:// www.odi.org/sites/odi.org.uk/files/odi-assets/publications-opinion-files/8937.pdf(accessed 23 February 2018).

Sultana Z. (2010) Impact of Monga on Rural Urban Migration: Its Socio- Economic Consequences. ASA University Review, 4 (2): 151-167.

Uddin A.M. (2013) Social Safety Nets in Bangladesh: An Analysis of Impact of Old Age Allowance Program. Available at: https://core.ac.uk/download/pdf/61804718.pdf (accessed 05 February 2018).

UN Millennium Project (2005) Investing in Development: A Practical Plan to Achieve the Millennium Development Goals. New York: UNO.

Winters P., Davis B., Corral L. (2002) Assets, Activities and Income Generation in Rural Mexico: Factoring in Social and Public Capital. Agricultural Economics, 27 (2): 139-156.

World Bank (2006) Social Safety Nets in Bangladesh: An Assessment. Available at: http:// documents.worldbank.org/curated/en/680721468199765276/Bangladesh-Social-safetynets-in-Bangladesh-an-assessment (accessed 13 January 2018).

Zug S. (2006) Monga-Seasonal Food Insecurity in Bangladesh- Bringing the Information Together. The Journal of Social Studies, (111): 1-14. 